\title{
Purification and Serology of Bean Yellow Mosaic Virus
}

\author{
Ichiro UYedA*, Makoto KoJIMA** \\ and Daiki Murayama** \\ 上田一郎*・小島 誠**・村山大記**：インゲン黄斑モザイク \\ ウイルスの精製と血清反応
}

\begin{abstract}
Isolate No. 30 of bean yellow mosaic virus (BYMV) was purified from broad bean leaves by extraction with $0.1 \mathrm{M}$ Tris- $\mathrm{HCl}$ buffer, $\mathrm{pH} 7.0$, containing $0.05 \mathrm{M}$ EDTA and $1 \%$ 2-mercaptoethanol; repeated clarification with carbon tetrachloride and precipitation with $4 \%$ polyethylene glycol $(\$ 6,000)$ followed by differential centrifugation and sucrose density-gradient centrifugation. ISCO fractionator scanning patterns indicated a high degree of purity but serological results revealed the presence of some host contaminates. The yield of virus was about $2 \mathrm{mg} / 100 \mathrm{~g}$ of broad bean leaves.

The titer of the antiserum against isolate No. 30 was $1 / 2048$ by ring precipitin tests. Although the intact virus particles could not diffuse in agar gel plates, a clear precipitin line was observed when $0.5 \%$ SDS (or LIS) was added to the agar or virus suspension. Isolate No. 30 was compared serologically with a necrotic strain and a chlorotic spot strain of BYMV in agar gel diffusion tests. Spur reactions were observed between isolate No. 30 and these strains.

(Received July, 1974)
\end{abstract}

\section{Introduction}

Purification of BYMA has been described by Bancroft and Keasberg') and Regenmoltel ${ }^{15)}$. Hewever, aggregation of virus to virus, and virus to host constituents during purification resulted in low yield of virus in the potato virus $\mathrm{Y}$ (PVY) group including BYMV. Unaggregated tobacco etch virus was obtained by using urea in the resuspending medium ${ }^{4}$. This method was applied to the serological study of BYMV ${ }^{20}$. Tris- $\mathrm{HCl}$ buffer containing EDTA was found to be useful for purification of BYMV ${ }^{19}$. This report describes a modification on the purification procedure for BYMV which produces relatively large amounts of unaggregated virus. Specific antiserum against isolate No. 30 of BYMV was successfully prepared by the procedure mentioned here. Serological reactions in agar gel plates were generally difficult in the filamentous virus particles. The present authors, however, succeded in testing the serological relationships between some strains of BYMV using a modification method of agar gel double diffusion test.

\section{Materials and method}

Virus source Isolate No. 30 of BYMV used in this study was obtained from French bean (Phaseolus vulgaris L.) 'Taisho Kintoki', collected from a field in Hokkaiko, Japan ${ }^{12}$.

* Present address: Irrigated Agriculture Research and Extension Center, Washington State University, Professer, Washington, USA.

** Faculty of Agriculture, Hokkaido University, Sapporo, Japan. 北海道大学農学部 
This isolate was propagated in broad bean (Vicia fabe L.) by mechanical inoculation under green house condition. Broad bean plants were inoculated at the 4-6 leaf stage. A necrotic strain ${ }^{8)}$ and a chlorotic spot strain $^{10)}$ of BYMV were also increased in broad bean and used for serological comparison with isolate No. 30 .

Identification Inocula were prepared from broad bean leaves infected 6-9 days by grinding in $0.1 \mathrm{M}$ Tris buffer, $\mathrm{pH}$. 7.0. Test plant leaves were dusted with carborundum prior to mechanical inoculation. Back inoculation was made on healthy broad bean or Chenopodium amaranticolor Coste \& Reyn. In insect transmission test, green peach aphid (Myzus persicae Sulz.) was starved for 1-2 hrs, and fed on infected broad bean for 2-5 min, and then immediately transferred to healthy pea (Pisum sativum L.), or broad bean plants using 5 aphids per plant. After $24 \mathrm{hrs}$ the aphids were killed by insecticide. Physical properties were determined by infectivity assays made on leaves of C. amaranticolor. The dip method was used to detect virus particles in crude sap from infected plants.

Purification About $20 \mathrm{~g}$ to $100 \mathrm{~g}$ of frozen infected broad bean leaves were crushed and macerated with twice their weight volume of $0.1 \mathrm{M}$ Tris buffer, $\mathrm{pH} 7.0$, in a mortar, and the juice expressed through two layers of cheesecloth. The extract was emulsified briskly for $3 \mathrm{~min}$ with cold $(4 \mathrm{C})$ carbon tetrachloride, and emulsion broken by centrifugation at 3,000 rpm for $15 \mathrm{~min}$ in a Marusan $9 \mathrm{~B}-2$ rotor. The virus was precipitated from the aqueous phase by $4 \%$ polyethylene glycol (PEG, M. W. 6,000) ${ }^{7}$ ) centrifuged at $6,000 \mathrm{rpm}$ for $15 \mathrm{~min}$ in a Marusan $9 \mathrm{~B}-2$ rotor, the pellet was suspended in $0.01 \mathrm{M}$ phosphate buffer, $\mathrm{pH} 7.4$, containing $0.5 \mathrm{M}$ urea and clarified again with half volume of cold carbon tetrachloride ${ }^{9)}$. Clarified extracts were then centrifuged for $15 \mathrm{~min}$ at $10,000 \mathrm{rpm}$ and supernatants were centrifuged for $90 \mathrm{~min}$ at $32,000 \mathrm{rpm}$ in a RP $60 \mathrm{~T}$ rotor using Hitachi $65 \mathrm{P}$ preparative ultracentrifuge. Pellets were suspended in $2 \mathrm{ml}$

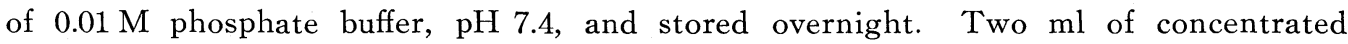
preparation were layered on rate density-gradient columns ${ }^{2)}$ prepared by layering 4,7 , 7 and $7 \mathrm{ml}$ of $100,100,300$ and $400 \mathrm{mg}$ sucrose $/ \mathrm{ml} 0.01 \mathrm{M}$ phosphate buffer, $\mathrm{pH} 7.4$, containing $0.5 \mathrm{M}$ urea in $2.5 \times 7.6 \mathrm{~cm}$ cellulose nitrate tubes and centrifuged at $24,000 \mathrm{rpm}$ for $120 \mathrm{~min}$ in a Hitachi RPS 25 rotor. Density-gradient colums were stored overnight at $4 \mathrm{C}$ prior to use. After sucrose density-gradient centrifugation, the virus was fractionated by an ISCO fractionator. Further details are given at the appropriate place in the text.

Assay Infectivity was tested on leaves of C. amaranticolor and half-leaf comparisons were used for quantitative assays. The degree of purity was estimatcd by ISCO fractionator scanning patterns, serology and ultraviolet absorption spectra.

The virus removed from a sucrose density-gradient column was pelleted by centrifugation at $32,000 \mathrm{rpm}$ for $90 \mathrm{~min}$ in a Hitachi $60 \mathrm{~T}$ rotor or centrifugation at $35,000 \mathrm{rpm}$ for $90 \mathrm{~min}$ in a Hitachi RP 40 rotor to remove sucrose and urea. The pellet was suspended in $0.01 \mathrm{M}$ phosphate buffer, $\mathrm{pH} 7.0$, and stored overnight at $4 \mathrm{C}$. This virus preparation was then examined with an electron microscope and a spectrophotometor.

Ultraviolet absorption spectra of the purified virus were determined with a Hitachi model 356 spectrophotometer or a Hitachi model 124 spectrophotometer.

Electron microscopy The purified virus and leaf dip preparations from infected plants were negatively stained with $2 \%$ phosphotungstic acid, $\mathrm{pH} 7.0$, and examined 
in a Hitachi HS-8 electron microscope.

Serology One $\mathrm{ml}$ of purified isolated No. $30\left(\mathrm{OD}_{260}=0.3\right)$ emulsified with $1 \mathrm{ml}$ of Freund's complete adjuvant was injected into a rabbit weekly for three weeks. A single intravenous injection was made two weeks after the last intramuscular injection. Antisera against the necrotic strain and chlorotic spot strain were prepared by the similar manner. Rabbits were bled one week after final injection. Healthy plant antigen was prepared from broad bean by the same purification procedure as used for virus antigen except the sucrose density-gradient centrifugation step.

Agar gel double diffusion tests were done according to the modified method of Uyemoto et al. (1972). Eight $\mathrm{ml}$ of agar (special agar-noble, DIFCO Lab., $0.85 \%$ in $0.01 \mathrm{M}$ phosphate buffer, $\mathrm{pH} 7.0$ ) containing $0.04 \%$ sodium azide and $0.85 \%$ saline was poured into $9 \mathrm{~cm}$ flat petri plates. The effect of $0.5 \%$ sodium dodecyl sulphate (SDS, Wako Junyaku Industudy) and 0.5\% 3, 5-diiodosalicylic acid lithium salt (LIS, Nakarai Chemicals, Ltd.) incoporated in agar or viral antigen was tested. The patterns in the agar consisted of 6 peripheral wells $(7 \mathrm{~mm}$ diam) around a center well $(7 \mathrm{~mm}$ diam), with $5 \mathrm{~mm}$ distance between the closest edges of the center and peripheral wells. The plates were incubated in a moist chamber at room temprature.

\section{Results}

\section{Identification}

Isolate No. 30 infected 12 of the 14 Leguminosae species tested and 3 of the 6 species tested from other families (Table 1). Systemically infected leaves of French bean 'Topcrop', 'Taisho Kintoki' and broad bean 'Wase-soramame' developed severe necrosis and eventually died. C. amaranticolor developed necrotic lesions on inoculated leaves.

Sap from broad bean was infective after $10 \mathrm{~min}$ at $55 \mathrm{C}$ but not $60 \mathrm{C}$, after dilution to $10^{-3}$ or $10^{-4}$, and after a few days at room temperature.

Sap from infected broad bean and C. amaranticolor contained flexuous filamentous particles when observed under an electron microscope (Plate I-A).

Isolate No. 30 was easily transmitted by green peach aphid in a non-persistent manner (Table 2).

On the basis of these results, isolate No. 30 was recognized as a strain of bean yellow mosaic virus ${ }^{8}$.

\section{Time of harvest and condition of extraction}

Because broad bean plants die about two weeks after inoculation with isolate No. 30, the time at which leaves were harvested was critical. Infectivity was highest in systemically infected leaves 7-9 deys after inoculation (Fig. 1). The virus yield was also higher from systemically infected leaves than from inoculated leaves as assessed by ISCO scanning pattern. Incubation for 1-2 hrs after maceration gave a high yield of virus.

\section{Extraction medium}

An antioxidant was needed to prevent darkening in crude extracts. Neither $0.02 \mathrm{M}$ 
Table 1. Reaction of plants to the No. 30 isolate by mechanical inoculation

\begin{tabular}{|c|c|c|c|c|}
\hline \multirow{2}{*}{ Plant species } & \multicolumn{2}{|c|}{ Symptom ${ }^{a)}$} & \multicolumn{2}{|c|}{ Back inoculation ${ }^{b}$ ) } \\
\hline & Ic) & S & I & $\mathrm{S}$ \\
\hline \multicolumn{5}{|l|}{ Phaseolus angularis W. F. Wight } \\
\hline 'Takara' & $\mathrm{N}$ & $\mathrm{M}, \mathrm{N}$ & + & + \\
\hline \multicolumn{5}{|l|}{ P. vulgaris $\mathrm{L}$. } \\
\hline 'Taisho Kintoki' & $\mathrm{N}$ & $\mathrm{N}$ & + & + \\
\hline ‘Topcrop' & $\mathrm{N}$ & $\mathrm{N}$ & + & + \\
\hline 'Toramame' & $\mathrm{N}$ & M & & + \\
\hline \multicolumn{5}{|l|}{ Pisum sativum $\mathrm{L}$. } \\
\hline 'Beikoku Ousaya' & - & $\mathrm{M}, \mathrm{N}$ & & + \\
\hline 'Wis. Perfection' & - & - & & - \\
\hline Vicia faba L. & $\mathrm{N}$ & $\mathrm{M}, \mathrm{N}$ & + & + \\
\hline V. villosa Roth & & $\mathrm{M}$ & & + \\
\hline Vigna sesquipedalis Fruwirth & C. $\mathrm{S}$ & C. S & + & + \\
\hline Glycine max Merr & - & M & + & + \\
\hline Trifolium pratense $\mathrm{L}$. & $\mathrm{N}$ & $\mathrm{N}$ & & + \\
\hline T. repens L. f. giganteum & - & M & + & + \\
\hline T. incarnatum $\mathrm{L}$. & - & M & & + \\
\hline T. hybridum L. & - & $\mathrm{M}, \mathrm{N}$ & & + \\
\hline Astragalus sinicus L. & - & M & & + \\
\hline Medicago sativa L. & - & - & 一 & - \\
\hline Chenopodium amaranticolor Coste \& Reyn & $\mathrm{L}$ & $\mathrm{L}$ & + & + \\
\hline Nicotiana tabacum L. & & & & \\
\hline 'White barley' & - & - & + & - \\
\hline N. glutinosa L. & - & - & - & - \\
\hline Cucumis sativus $\mathrm{L}$. & - & - & - & - \\
\hline Cucurbita moschata Duch & - & - & - & - \\
\hline Sesamum indicum L. & $\mathrm{N}$ & $\mathrm{N}$ & & + \\
\hline
\end{tabular}

a) $\mathrm{N}$ : necrosis, $\mathrm{M}$ : mosaic, L: local lesion, C.S : chlorotic spot, - : no symptoms.

b) Back inoculations were made on C. amaranticolor or broad bean.

c) I: inoculated leaves, S: systemic leaves.

Table 2. Transmission of isolate No. 30 by green peach aphids

\begin{tabular}{cc}
\hline \hline Test plant & No. of infected plants \\
\cline { 2 - 2 } Pisum sativum L. & $2 / 7$ \\
Vicia faba L. & $7 / 7$ \\
\hline
\end{tabular}


ascorbic acid nor $0.02 \mathrm{M}$ sodium diethyldithiocarbamate (DIECA) prevented darkening. 2-mercaptoethanol $(1 \%)$ not only prevented darkening but also removed green pigment and host constituents when extracts were clarified with organic solvent such as carbon tetrachloride. Ethylenediaminetetraacetic acid (EDTA) (0.05M) effectively removed host constituents as determined by ISCO scanning patterns.

Effect of these chemicals on infectivity in crude extracts was also tested (Table 3). EDTA $(0.05 \mathrm{M})$ and $1 \% 2$-mercaptoethanol stabilized virus infectivity.

\section{Clarification}

Infectivity remained high in crude extracts clarified with carbon tetrachloride or chloroform compared with other clarification treatments or crude extracts. A large proportion of the infectivity was lost when extracts were treated with half volume of a mixture of $n$-butanol and chloroform $(1: 1)$ or $n$-butanol alone (Table 4$)$. Carbon tetrachloride, therefore, was used in this study. After PEG precipitation the pellet was still green

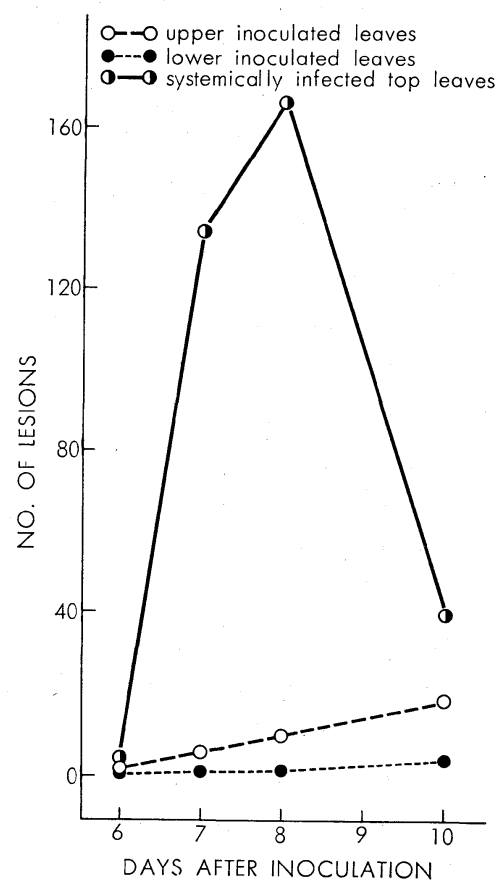

Fig. 1. Rate of isolate No. 30 increase in systemically infected and inoculated leaves of Vicia abfa. and concentrated suspension of this pellet was not clear. Consequently a second clarification was made with carbon tetrachloride. This treatment removed some host constituents and green pigment though not completely. A clear aqueous phase with some protein light scattering was obtained.

\section{Resuspending medium}

Several resuspending media used for purification of viruses in the PVY group were

Table 3. Effect of some antioxidants and EDTA on infectivity of isolate No. 30 in crude extracts $^{\text {a) }}$

\begin{tabular}{|c|c|c|c|}
\hline \multirow{2}{*}{ Chemicals } & \multicolumn{2}{|c|}{ No. of lesions/half leaf } & \multirow{2}{*}{$\begin{array}{c}\text { Infectivity } \\
\text { retained for } 6 \mathrm{hrs} \\
\%\end{array}$} \\
\hline & $0 \mathrm{hr}$ & $6 \mathrm{hrs}$ & \\
\hline $0.02 \mathrm{M}$ ascorbic acid & 98 & 62 & 63 \\
\hline $0.02 \mathrm{M}$ DIECA & 35 & 9 & 26 \\
\hline $1 \%$ 2-mercaptoethanol & 54 & 31 & 59 \\
\hline $0.05 \mathrm{M}$ EDTA & 24 & 21 & 87 \\
\hline $0.01 \mathrm{M}$ Tries buffer, $\mathrm{pH} 7.0$ & 144 & 54 & 38 \\
\hline
\end{tabular}

a) All the antioxidants and EDTA were in $0.1 \mathrm{M}$ Tris buffer, $\mathrm{pH}$ 7.0. Frozen infected leaves were macerated with twice their weight volume of buffer and expressed through two layers of cheesecloth. Extracts were inoculated immediately and after $6 \mathrm{hrs}$ incubation at $4 \mathrm{C}$. 
Table 4. Infectivity of isolate No. 30 after clarification with various solventsa)

\begin{tabular}{|c|c|c|c|c|}
\hline \multirow{3}{*}{ Treatment } & \multicolumn{4}{|c|}{ No. of lesions/half leaf } \\
\hline & \multicolumn{4}{|c|}{ trial } \\
\hline & $\mathrm{a}$ & $\mathrm{b}$ & $\mathrm{c}$ & d \\
\hline \multicolumn{5}{|l|}{ Carbon tetrachloride } \\
\hline (1 vol/extracts 2 vol) & & 29 & 62 & 130 \\
\hline (1 vol/extracts $1 \mathrm{vol})$ & & 30 & & \\
\hline \multicolumn{5}{|c|}{$1: 1$ mixture of $n$-butanol and chloroform } \\
\hline (1 vol/extracts $2 \mathrm{vol})$ & & & & 23 \\
\hline \multicolumn{5}{|l|}{$n$-Butanol } \\
\hline (1 vol/extracts $2 \mathrm{vol})$ & & & & 5 \\
\hline \multicolumn{5}{|l|}{ Chloroform } \\
\hline (1 vol/extracts $2 \mathrm{vol})$ & & & & 132 \\
\hline \multicolumn{5}{|l|}{ Fluorocarbon } \\
\hline (1 vol/extracts 2 vol) & & & & 119 \\
\hline Crude extracts & 20 & & 24 & \\
\hline $\begin{array}{l}\text { Crude extracts after centrifugation } \\
\text { at } 3,000 \mathrm{rpm}\end{array}$ & 11 & 9 & & \\
\hline
\end{tabular}

a) Frozen infected leaves were macerated with twice their weight volume of $0.1 \mathrm{M}$ Tris buffer, $\mathrm{pH}$ 7.0, and expressed through two layers of cheesecloth. Mixture of extracts and the solvent was emulsified briskly for $3 \mathrm{~min}$ and the emulsion was broken by centrifugation at $3,000 \mathrm{rpm}$ for $15 \mathrm{~min}$.

tested to determine which was best for the isolate No. 30. After clarification with carbon tetrachloride the aqueous phase was divided into 6 aliquots and the virus was precipitated from each by $4 \%$ PEG. These pellets were suspended in several resuspending media and subjected to the second clarification with carbon tetrachloride, differential centrifugation and sucrose density-gradient centrifugation. Serious virus aggregation occurred when pellets were suspended in $0.05 \mathrm{M} \mathrm{Na-citrate}{ }^{15)}, \mathrm{pH} 7.0$, and $0.05 \mathrm{M}$ Na-borate, $\mathrm{pH}$ 8.2. Incoporation of $0.5 \mathrm{M}$ urea into $0.01 \mathrm{M}$ phosphate buffer, $\mathrm{pH}$ 7.4, effectively prevented virus aggregation and produced a high yield of virus.

$0.01 \mathrm{M}$ Tris buffer, $\mathrm{pH} 8.0^{19}$, also gave a high yield and less aggregated virus, but $0.01 \mathrm{M}$ phosphate buffer, $\mathrm{pH} 7.4$, removed green pigment and host constituents which had an absorbance at $254 \mathrm{~nm}$ at a meniscus in sucrose density-gradient column more effectively than $0.01 \mathrm{M}$ Tris buffer, $\mathrm{pH}$ 8.0. The final purification procedure is illustrated in Fig. 2.

\section{Sucrose density-gradient centrifugation}

Usually two virus zones were obtained, the main zone was $27-29 \mathrm{~mm}$ below the meniscus and the second zone was about $2 \mathrm{~mm}$ apart below the main zone (Plate II-A). In another pattern, light-scattering zone started $27-29 \mathrm{~mm}$ below the meniscus and gradually decreased its scattering corresponding a slow skewing downward curve of ISCO fractionator scanning pattern (Plate II-B). These zones were associated with infectivity (Fig. 3). These two zones were fractionated by ISCO fractionator and 


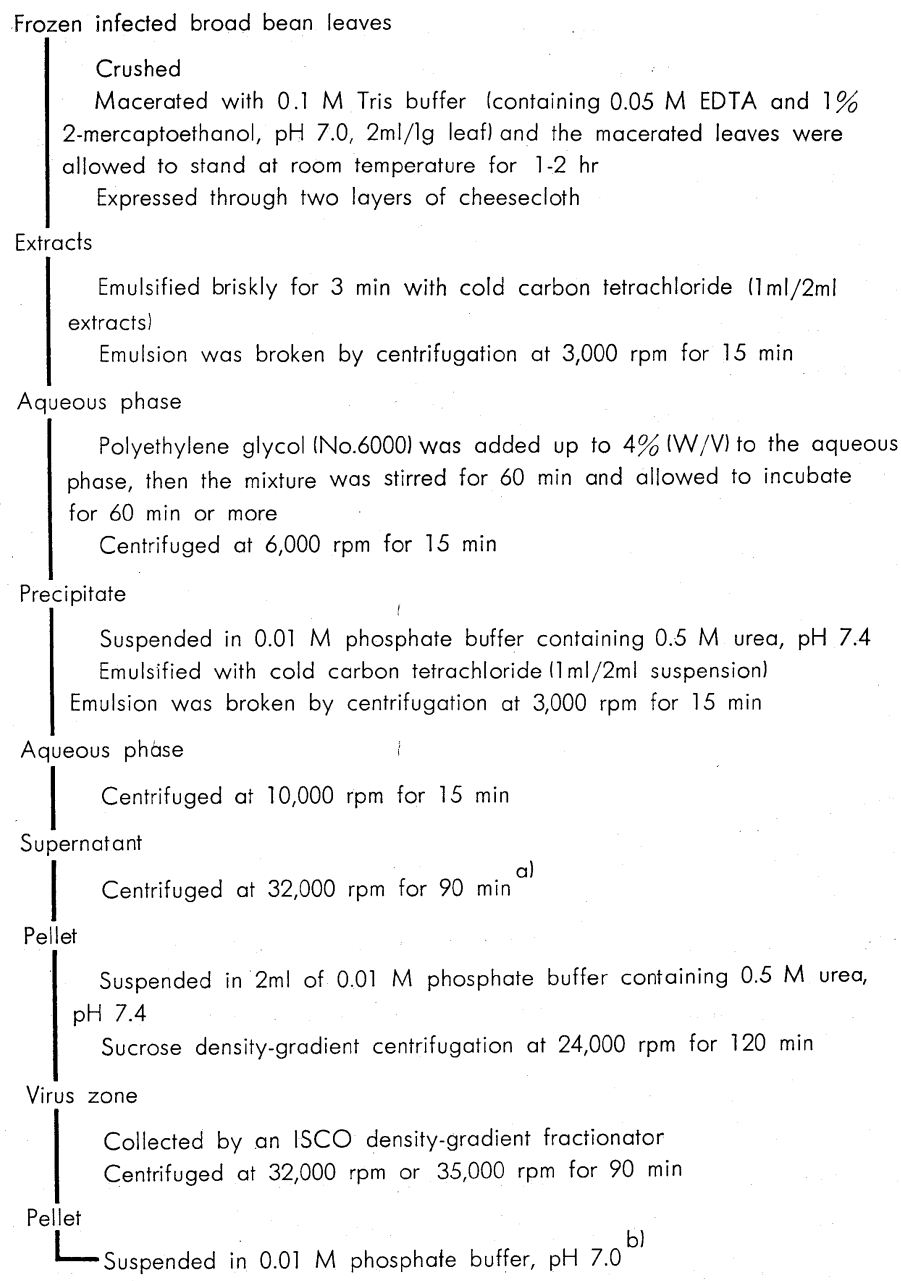

a) Instead of a cycle of differential centrifugation, two cycles of differential centrifugation was done for antiserum production.

b) $0.85 \%$ saline was added to this buffer for antiserum production.

All procedures except for maceration were done at $4 \mathrm{C}$.

Fig. 2. Final purification procedure of BYMV

examined serologically and inoculated to broad bean. No difference was detected in the reaction in an agar gel diffusion test and in symptoms developed on broad bean. When $0.02 \mathrm{M}$ DIECA was added to extracting medium, a faint zone which had an absorbance at $254 \mathrm{~nm}$ was detected $2 \mathrm{~mm}$ above the main zone. This zone could not be detected when $1 \% 2$-mercaptoethanol was added to extracting medium instead of 0.02 M DIECA.

\section{Electron microscopy}

Electron micrographs of purified isolate No. 30 obtained from the main light scattering zone in sucrose density-gradient columns revealed numerous unaggregated virus particles (Plate I-B). The most frequent length (36\% of the total particles measured) in the modal distribution was about $800 \mathrm{~nm}$. 


\section{Ultraviolet absorption}

Purified isolate No. 30 obtained from the main virus zone in a sucrose densitygradient column showed typical absorption spectrum of rod shaped virus which has a slight shoulder at $290 \mathrm{~nm}$ (Fig. 4).

Maximum and minimum absorbance was at $260 \mathrm{~nm}$ and $245-246 \mathrm{~nm}$, respectively.

A ratio of $260 / 280$ of several preparations, corrected for light scattering ${ }^{6)}$, varied from 1.24 to 1.31 , with an average of 1.28 . A ratio of $\mathrm{max} / \mathrm{min}$, similarly corrected,

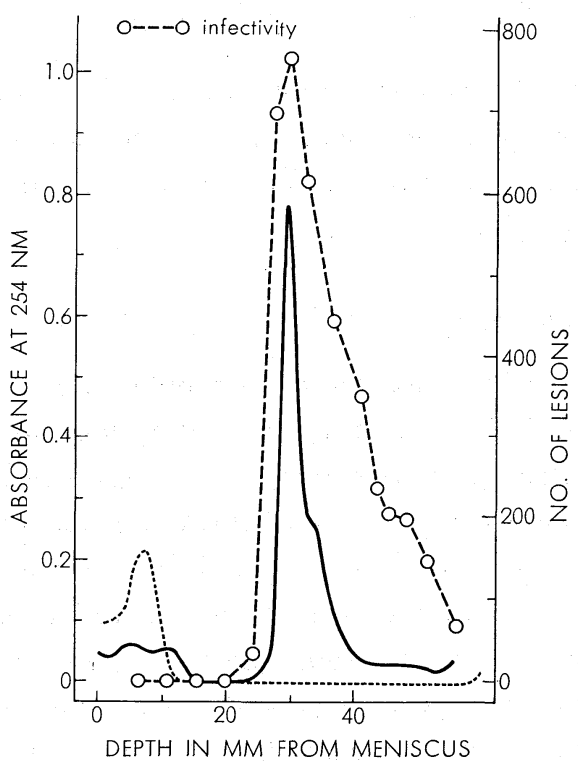

Fig. 3. Infectivity of fractions removed from density-gradient columns and ISCO scanning patterns after sucrose density-gradient centrifugation of isolate No. 30. Solid and dotted curves are patterns of infected and healthy plants fractionated by the final purification procedure, respectively. varied from 1.38 to 1.58 , with an average of 1.50 .

A necrotic strain and a chlorotic spot strain showed the similar patterns and a average ration of $260 / 280$ was 1.24 and 1.19 , $\mathrm{max} / \mathrm{min}$ was 1.57 and 1.68 , respectively.



Fig. 4. Observed ultraviolet absorption spectrum of the purified No. 30 isolate.

\section{Serology}

The titer of antisera in a ring test using the viral antigen $\left(\mathrm{OD}_{260}=0.01\right)$ was shown in Table 5. Although the virus could not diffuse in agar gel, a clear precipitin line was usually observed within $12 \mathrm{hrs}$ when $0.5 \%$ SDS was added to the agar or virus suspension (Plate III). Second line developed which was due to the reaction between healthy broad bean constituents and antibody. This line formed close to the antiserum well after 2 day's incubation in some experiments (Plate III-A). Crude sap from infected broad bean leaves also reacted with the antiserum in agar gel plates containing $0.5 \%$ SDS (Plate III-B).

Both the necrotic strain and the chlorotic spot strain of BYMV reacted with the antiserum against isolate No. 30 in agar gel containing 0.5\% SDS. However, spur reactions were obseved between these strains and the isolate No. 30 (Plate IV-A, B). Serological relationships between these viruses were examined in argar gel plates 
Table 5. The reciprocals of homologous and heterogous end-point of antisera to isolate No. 30 and two other strains of BYMV

\begin{tabular}{lccc}
\hline \hline \multirow{2}{*}{ Antigen } & \multicolumn{3}{c}{ Antiserum prepared against } \\
& Isolate No. 30 & Necrotic strain & Chlorotic spot strain \\
\hline Isolate No. 30 & 2048 & 1024 & 1024 \\
Necrotic strain & 1024 & 1024 & 1024 \\
Chlorotic spot strain & 1024 & 1024 & 1024 \\
\hline
\end{tabular}

containing $0.5 \%$ LIS. Similar reaction was detected and the spur fromation is more clear than that in SDS (Plate IV-C). Further investigations were done using antisera against the necrotic strain and chlorotic spot strain in agar gel plates containing $0.5 \%$ LIS. Spur reactions were observed in each case (Plate IV-D, E).

\section{Discussion and conclusion}

Aggregation of virus during purification is a limiting factor for obtaining high yields of viruses in the PVY group. Much virus is lost during the initial low speed centrifugation $^{18)}$ suggesting that the loss of the virus may be mainly due to aggregation of virus particles with host constituents. Consequently, the choice of extracting medium, initial clarification method and source of virus are important in obtaining maximum virus yield during purification ${ }^{16), 17)}$. Broad bean was found to be a more suitable propagation host than pea for isolate No. 30 because broad bean appears to be more susceptible to this isolate and easier to handle than pea. A good clarification was achieved by adding EDTA and 2-mercapto-ethanol into extracting medium. Several detergents have been used for dispersion of aggergated viruses ${ }^{3,413)}$. Effect of urea on aggregation of virus particles was tested and the results agreed with that of Damirdagh and Shepherd ${ }^{4}$.

Another problem on purification of viruses in PVY group is that multiple virus zones are usually detected in sucrose density-gradient colmns ${ }^{4,5,18)}$. This problem also occured in this study. The zone below the main zone or the strong trailing light scattering from the main zone were detected in sucrose density-gradient columns. The close association of infectivities with these zones indicated that these zones were due to aggregation of virus particles.

The yield of purified isolate No. 30 was about $2 \mathrm{mg} / 100 \mathrm{~g}$ of broad bean leaves in best host condition according to a assumption of the absorbance value of 2.4 at $260 \mathrm{~nm}$ for $1 \mathrm{mg}$ virus $/ 1 \mathrm{ml}$ in a $1 \mathrm{~cm}$ path cell. Both the necrotic strain and the chlorotic strain of BYMV were also sufficiently purified by the final purification procedure of isolate No. 30 .

Development of agar-gel double diffusion tests for filamentous viruses has prove difficult. Some treatments are required to degrade virus particles into readily diffusible units. Recently, Uyemoto et al..$^{20}$ found that pyrrolidine and SDS were effective in degrading BYMV and bean common mosaic virus for the purpose of testing in agar gel plates. The application of some detergents to three isolates of BYMV was described herein. LIS-agar was as effective as SDS in degrading viruses but LIS-agar serology was less erratic. This application made a comparative serological study of some strains 
of BYMV possible. It was found that isolate No. 30 and other two strains of BYMV were distinguished serologically by spur formation in the treated agar gel plates.

\section{Acknowledgement}

We are indebted to Dr. G. I. Mink, Washington State Univ., for his helpful suggestions and review of this manuscript.

\section{Literature cited}

1) Bancroft, J. B. and Kaesberg, P. (1959). Phytopathology 49 : 713-715.

2) Brakke, M. K. (1959). Virology 9: 506-521.

3) Brakke, M. K. (1960). Adv. Virus Res. $7: 193-224$.

4) Damirdagh, I. S. and Shepherd, R. J. (1970). Phytopathology $60: 132-142$.

5) Delgado-Sanchez, S. and Grogan, R. G. (1966). Phytopathology 56 : 1397-1404.

6) Englander, S. W. and Epstein, H. T. (1957). Arch. Biochem. Biophys. 68 : 144-149.

7) Hebert, T. T. (1963). Phytopathology 53: 362.

8) Inouye, T. (1968). Nogaku Kenkyu 52:11-29.

9) Kojima, M. and Murayama, D. (1972). Ann. Phytopath. Soc. Japan 38: 431-433.

10) Kume, H., Tanaka, S. and Murayama, D. (1970). Mem. Fac. Agr. Hokkaido Univ. $7: 435-449$.

11) Milne, K. S. and Grogan, R. G. (1969). Phytopathology 59: 809-818.

12) Murayama, D., Shikata, E., Kojima, M., Senboku, T., Kajiwara, K. (1975). Mem. Fac. Agr. Hokkaido Univ. 9 : 155-159.

13) Nozu, Y. and Yamaura, R. (1971). Virology 43: 514-515.

14) Purcifull, D. E. (1966). Virology $29: 8-14$.

15) van Regenmotel, M. H. V. (1964). Virology $23: 495-502$.

16) Ross, J. P. (1967). Phytopathology $57: 465-467$.

17) de Sequeira, O. A. and Lister, R. M. (1969). Phytopathology $59: 1740-1749$.

18) Shepherd, R. J. and Pound, G. S. (1960). Phytopathology $50: 797-802$.

19) Suzuki, M. (1972). M. A. Thesis Hokkaido Univ.

20) Uyemoto, J. K. and Prov. Identi, R. and Schroeder, W. T. (1972). Ann. Appl. Biol. 71: 235-242.

\section{和文摘要}

\section{インゲン黄斑モザイクウイルスの精製と血清反応}

$$
\text { 上田一郎 · 小島 誠 · 村山大記 }
$$

インゲン黄斑モザイクゥイルス（BYMV, isolate No. 30) を精製し，抗血清を作製した。罹病ソラマメ茎 葉 (凍結組織)を0.1 Mトリス緩衝液 (0.05 M EDTA，1\% 2-メルカプトエタノールを含む， pH 7.0) 中で磨砕 し, 四塩化炭素による清澄化の後, $4 \%$ ポリエチレングリコール(\#6000)により濃縮し, さらに分画遠心後, しょ糖濃度勾配遠心法により精製した。ウイルス収量は罹病ソラマメ $100 \mathrm{~g}$ あたり約 $2 \mathrm{mg}$ であった。


ゲル二重拡散法では反応が認められなかった。しかしラウリル硫酸ナトリウム (SDS)を寒天中に加えるか， あるいはSDSによってウィルスを処理すると，1本の沈降線が認められた。この方法により既知の 2 系統 (BYMV-N 系統, BYMV-CS 系統) との血清学的関係を調らべたところ, いずれも本分離株との間にはスパー が形成された。SDS の代りに3，5-ジョードサリチル酸リチウム（LIS）を用いた場合，より明膫な沈降線（ス パーも含む) が得られた。 


\section{Explanation of plates}

I Electron micrographs of $\operatorname{dip}(\mathrm{A})$ and purified (B) preparations of isolate No. 30. $\mathrm{Bar}=500 \mathrm{~nm}$.

II Sucrose density-gradient columns after centrifugation. (A) necrotic strain, (B) isolate No. 30.

III Homologous reaction between isolate No. 30 and its antiserum in agar gel diffusion plates. Center wells contained the undiluted antiserum. SDS $(0.5 \%)$ was incorporated into antigen preparation (A) or into agar (B).

1,2 and $2^{\prime \prime}$ : Purified healthy antigen, isolate No. $30\left(\mathrm{OD}_{260}=0.5\right)$ and isolate No. 30 $\left(\mathrm{OD}_{260}=0.25\right)$ respectively.

$1^{\prime}$ and $2^{\prime}$ : Sap from healthy and infected broad bean leaves extracted with twice volume of their weight of $0.1 \mathrm{M}$ Tris buffer, $\mathrm{pH} 7.0$, respectively.

IV Serological reaction between isolate No. 30, necrotic strain and chlorotic spot strain in agar gel diffusion plates containing $0.5 \%$ SDS $(\mathrm{A}, \mathrm{B})$ and $0.5 \%$ LIS $(\mathrm{C}, \mathrm{D}, \mathrm{E})$.

$1,2,3,1^{\prime}, 2^{\prime}$ and $3^{\prime}$ : Purified isolate No. 30 , necrotic strain and chlorotic spot strain $\left(\mathrm{OD}_{260}=0.5\right)$ and sap from broad bean infected with isolate No. 30 necrotic strain and chlorotic spot strain, respectively.

A 1, A 2 and A 3: Undiluted antisera against isolate No. 30, necrotic strain and chlorotic spot strain, respectively. 
Plate I
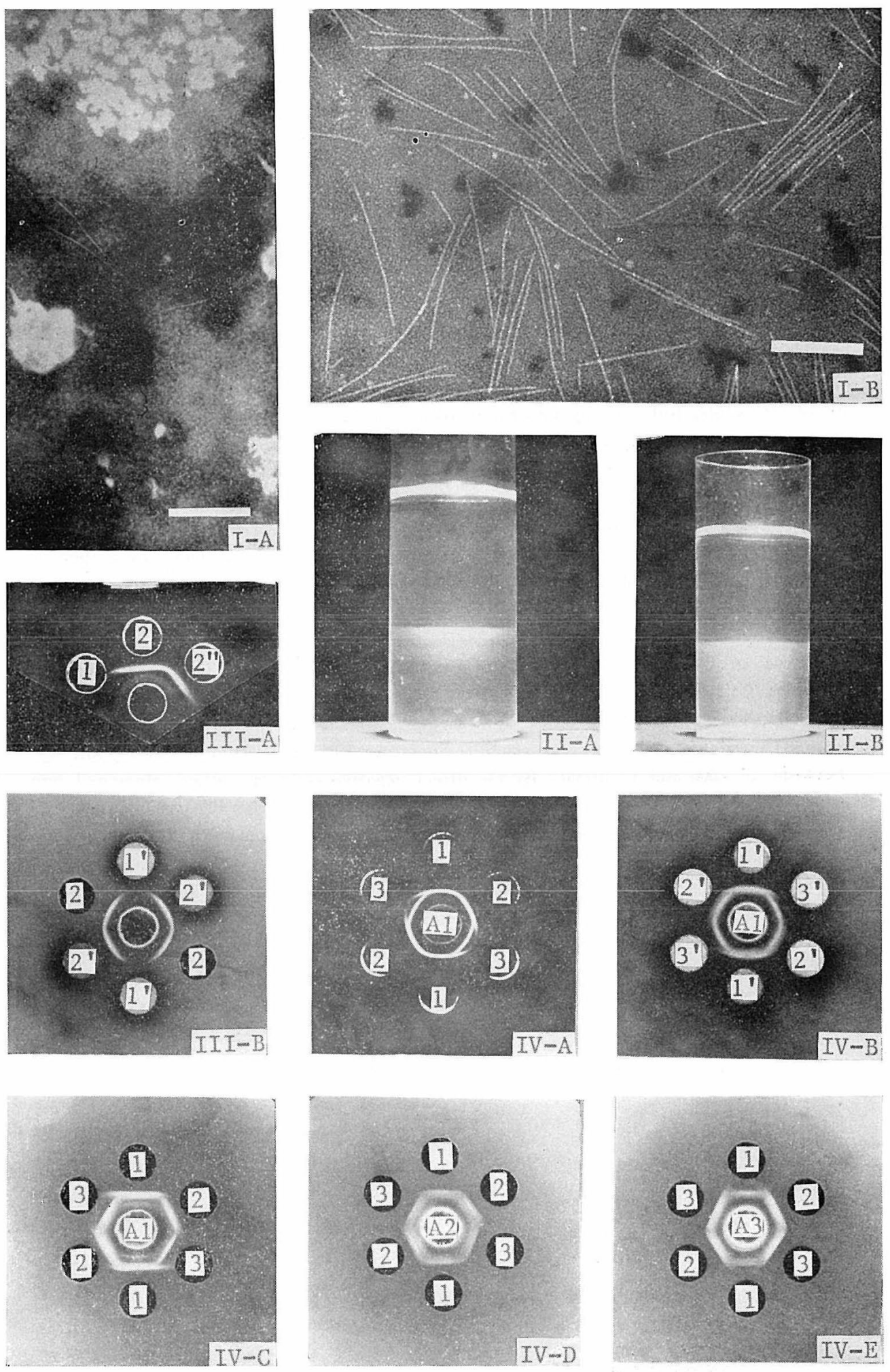